\title{
Pengembangan lembar kegiatan siswa (LKS) berbasis discovery learning pada materi bentuk aljabar untuk siswa kelas VII SMP Miftahul Huda Kabupaten Blitar
}

\author{
Octavita Cahyaningtyas, Santi Irawati* \\ Universitas Negeri Malang, Jl. Semarang No. 5 Malang, Jawa Timur, Indonesia \\ *Penulis korespondensi, Surel: santi.irawati.fmipa@um.ac.id
}

Paper received: 01-09-2021; revised: 15-09-2021; accepted: 30-08-2021

\begin{abstract}
The purpose of the development carried out is to produce student activity sheet based on discovery learning on algebra for grade VII students of Miftahul Huda Middle School in Blitar Regency that is valid, practical, and effective. The development model refers to the ADDIE development model which consists of: analysis, design, development, implementation, and evaluation. The results showed that LKS was declared valid with a validity score of 3.43. Student's activity sheet also fulfills practical criteria based on student response questionnaires with a practicality score of 3.5 , based on the observation sheet of teacher activity with a practicality score of 3.8, and based on the observation sheet of student activity with a practicality score of 3.66. The developed student worksheets also fulfills the effective criteria with a percentage of 90 percent of students getting a score above the minimum pass criteria
\end{abstract}

Keywords: student activity sheets; discovery learning; algebra

\begin{abstract}
Abstrak
Tujuan penelitian ini yaitu untuk menghasilkan LKS berbasis discovery learning pada materi bentuk aljabar bagi siswa kelas VII SMP Miftahul Huda Kabupaten Blitar yang valid, praktis, dan efektif. Model pengembangan merujuk pada model pengembangan ADDIE yaitu: analisis, desain/perancangan, pengembangan, implementasi, dan evaluasi. Hasil validasi menunjukkan bahwa LKS dinyatakan valid dengan skor kevalidan 3,43. LKS juga memenuhi kriteria praktis berdasarkan angket respon siswa dengan skor kepraktisan 3,5, berdasarkan lembar observasi aktivitas guru dengan skor kepraktisan 3,8, dan berdasarkan lembar observasi aktivitas siswa dengan skor kepraktisan 3,66. LKS yang dikembangkan juga memenuhi kriteria efektif dengan persentase 90 persen siswa mendapat nilai di atas KKM.
\end{abstract}

Kata kunci: Lembar Kegiatan Siswa (LKS); discovery learning; bentuk aljabar.

\section{Pendahuluan}

Matematika adalah salah satu pelajaran wajib dalam kurikulum 2013. Matematika merupakan mata pelajaran penting yang diberikan pada tingkat sekolah maupun perguruan tinggi dan memiliki peran penting dalam perkembangan ilmu dan teknologi. Matematika memiliki empat cabang yaitu aljabar, geometri, aritmatika, dan analisis. Zahid \& Imam (2017) mengungkapkan bahwa pentingnya penguasaan dasar-dasar aljabar untuk digunakan dalam memahami konsep-konsep matematika yang lain. Materi aljabar dipelajari di tingkat SMP kelas VII semester I. Standar kompetensi menganai materi aljabar yaitu mengenal bentuk aljabar dan unsur-unsurnya dan melakukan operasi bentuk aljabar (Permendikbud, 2016).

Berdasarkan hasil wawancara peneliti dengan guru matematika kelas VII SMP Miftahul Huda Kabupaten Blitar menunjukkan bahwa kemampuan aljabar siswa SMP kelas VII masih rendah. Selain itu, berdasarkan uji pendahuluan yang dilakukan peneliti terhadap 15 siswa di sana, kesulitan yang ditemui yaitu, (1) siswa sulit membedakan suku yang sejenis dan suku yang tak sejenis (73\% siswa salah dalam menjawab soal) dan (2) siswa masih kesulitan 
dalam mengoperasikan bentuk aljabar (60\% siswa mengalami kesalahan dalam menjawab soal).

Hasil wawancara selanjutnya diketahui bahwa guru menggunakan buku paket matematika sebagai buku pegangan siswa, LKS yang berisi latihan-latihan soal sebagai tambahan sumber belajar, dan kegiatan pembelajaran terlaksana sesuai RPP yang dibuat guru. Berdasarkan kegiatan inti di RPP yang disusun guru, tertulis bahwa guru menjelaskan permasalahan yang berkaitan dengan materi bentuk aljabar dan memberikan LKS yang berisi latihan-latihan soal pada siswa, sedangkan siswa hanya mendengarkan penjelasan guru setelah itu mengerjakan latihan soal pada LKS yang diberikan. Kegiatan inti tersebut tidak memungkinkan siswa terlibat aktif dalam menemukan suatu konsep. Jika siswa terlibat aktif dalam menemukan suatu konsep maka daya ingat siswa akan lebih lama dan siswa akan mampu mengaplikasikannya pada permasalahan yang berbeda (Trianto, 2010). LKS yang diberikan kepada siswa hanya menyajikan latihan soal mengenai materi yang dibahas tanpa melibatkan siswa dalam menemukan pengertian serta konsep yang ada pada materi sedangkan menurut Trianto (2010) diketahui bahwa LKS harus memuat beberapa kegiatan mendasar yang harus dilakukan siswa untuk memaksimalkan pemahaman mereka. Hal ini bertentangan dengan LKS yang guru berikan kepada siswa sehingga siswa tidak dapat maksimal dalam pembentukan kemampuan untuk menemukan konsep yang ada pada materi.

Upaya untuk mengatasi permasalahan tersebut adalah dengan melibatkan siswa secara aktif antara lain dengan cara menggunakan bahan ajar yang sesuai dengan karakter siswa sebagai penunjang buku paket yang telah diberi oleh pemerintah. Berdasarkan hasil wawancara kepada guru diketahui bahwa buku paket yang digunakan sebagai buku pegangan siswa menggunakan bahasa yang sulit dimengerti oleh siswa. Guru tidak memiliki kuasa untuk mengubah buku paket yang telah diberi oleh pemerintah tersebut, sehingga guru bisa menggunakan bahan ajar berupa Lembar Kegiatan Siswa (LKS) yang dapat disesuaikan dengan karakter siswa. Selain itu LKS dapat membuat siswa aktif dalam pembelajaran karena di dalam LKS terdapat beberapa kegiatan yang menuntun siswa aktif dalam menemukan konsep.

Metode yang dapat digunakan guru untuk menuntun siswa aktif menemukan suatu konsep yaitu metode discovery learning. Menurut Kemendikbud discovery learning merupakan teori belajar apabila siswa tidak diberikan materi pelajaran dalam bentuk final, namun siswa dibimbing untuk menemukan sendiri pemahaman dari materi pelajaran tersebut. Discovery learning lebih menekankan pada pembelajaran aktif berpusat pada siswa sehingga siswa dapat mengemukakan ide mereka sendiri dan memperoleh makna pembelajaran secara mandiri.

Berdasarkan uraian di atas, maka peneliti mengembangkan Lembar Kegiatan Siswa (LKS) berbasis discovery learning yang dapat memungkinkan siswa untuk aktif dalam menemukan suatu konsep. LKS berbasis discovery learning tidak langsung memberikan rumus, melainkan memberikan langkah-langkah untuk siswa menemukan sendiri suatu konsep. Langkah-langkah pada LKS berbasis discovery learning menurut Alma, dkk (dalam Muhardi, 2018), yaitu siswa diminta untuk merumuskan pertanyaan, merumuskan hipotesa, mengumpulkan dan mengolah data, dan merumuskan kesimpulan. 
Berdasarkan uraian di atas, penting untuk dilakukan pengembangan LKS berbasis discovery learning materi bentuk aljabar bagi siswa kelas VII SMP Miftahul Huda Kabupaten Blitar.

\section{Metode}

Penelitian ini termasuk jenis penelitian pengembangan yang bertujuan mengembangkan produk bahan ajar yaitu Lembar Kerja Siswa (LKS) pada materi bentuk aljabar untuk kelas VII SMP. Model pengembangan yang peneliti gunakan dalam pengembangan LKS berbasis discovery learning yaitu model pengembangan ADDIE. Pengembangan dalam model ADDIE yaitu tahap analisa (analysis), desain/perancangan (design), pengembangan (development), implementasi (implement), dan evaluasi (evaluate).

Alur pengembangan LKS berawal pada tahap analisis yaitu melakukan analisis kebutuhan, analisis kurikulum dan analisis karakteristik. Analisis kebutuhan diperoleh melalui wawancara kepada guru matematika SMP Miftahul Huda Kabupaten Blitar dan uji pendahuluan kepada 15 siswa yang telah menempuh materi bentuk aljabar dan diperoleh beberapa kesulitan siswa. Selanjutnya analisis kurikulum yaitu berdasarkan kurikulum yang berlaku diperoleh indikator pencapaian KD yang digunakan sebagai dasar untuk pengembangan LKS yang akan disusun. Analisis karakteristik diperoleh melalui wawancara peneliti dengan guru matematika dan diketahui siswa kelas VII lebih suka belajar secara berkelompok daripada bekerja individu karena dengan berkelompok mereka bisa berdiskusi dengan temannya dalam menyelesaikan masalah. Selanjutnya peneliti merancang LKS, RPP, soal tes formatif, angket respon siswa, lembar observasi guru dan siswa beserta lembar validasinya pada tahap desain. Kemudian rancangan LKS direalisasikan pada tahap pengembangan dan diuji kevalidannya oleh validator ahli dan validator praktisi. Setelah dinyatakan valid, LKS dapat diimplementasikan pada situasi nyata yaitu kelas VII SMP Miftahul Huda Kabupaten Blitar. Siswa diminta untuk mengerjakan LKS dan soal tes formatif serta mengisi angket respon siswa sedangkan guru dan salah satu mahasiswa yang berperan sebagai observer mengisi lembar observasi aktivitas guru dan siswa untuk setiap pertemuan. Hal ini diperlukan untuk mengetahui tingkat kepraktisan dan keefektifan LKS. Perhitungan tingkat kepraktisan dan keefektifan LKS dilakukan pada tahap evaluasi sehingga diperoleh LKS yang valid, praktis dan efektif.

Penelitian dilakukan pada semester ganjil tahun ajaran 2018/2019. Uji coba dilakukan di SMP Miftahul Huda Kabupaten Blitar dengan subjek uji coba yaitu 21 siswa kelas VII A. Data yang peneliti peroleh dari hasil uji coba adalah data kualitatif dan data kuantitatif. Data kualitatif berupa tanggapan, dan saran berdasarkan hasil penskoran validator pada lembar validasi serta lembar angket respon siswa. Data kuantitatif berupa skor penilaian yang diberikan oleh validator, skor hasil angket respon siswa, skor lembar observasi aktivitas guru dan siswa, serta skor siswa dalam tes formatif. Data kuantitatif dianalisis berdasarkan teknik analisis data kuantitatif yang diadaptasi dari Hobri (2010).

\section{Hasil dan Pembahasan}

\subsection{Hasil}

Data hasil validasi didapat dari penilaian oleh validator ahli dan validator praktisi. Validator ahli yaitu satu dosen prodi pendidikan matematika Universitas Negeri Malang yang telah menempuh pendidikan S2 dan validator praktisi yaitu satu guru matematika yang telah menempuh pendidikan S1. Lembar validasi terdiri atas lembar validasi lembar kegiatan 
siswa, lembar validasi RPP, lembar validasi angket respon siswa, lembar validasi soal tes formatif, lembar validasi aktivitas guru dan lembar validasi aktivitas siswa. Data yang didapat dari pengisian lembar validasi adalah data kualitatif dan data kuantitatif. Data kualitatif yaitu komentar atau saran yang diberikan oleh validator. Sedangkan data kuantitatif berupa skor pengisian lembar validasi oleh masing-masing validator pada setiap indikator.

Hasil skor rata-rata lembar validasi LKS yang diisi oleh validator ahli dan validator praktisi adalah 3,43 dengan kriteria valid. Komentar atau saran yang diberikan validator terhadap LKS yang dikembangkan yaitu kolom pada tahap ayo mengumpulkan informasi di kegiatan 1 terlalu banyak sehingga memakan waktu. Hasil skor rata-rata lembar validasi RPP yang diisi oleh validator ahli dan validator praktisi adalah 3,45 dengan kriteria valid. Komentar atau saran yang diberikan validator terhadap LKS yang dikembangkan yaitu kata kerja pada tujuan pembelajaran hendaknya dibuat lebih operasional lagi. Hasil skor rata-rata lembar validasi soal tes formatif yang diisi oleh validator ahli dan validator praktisi adalah 3,42 dengan kriteria valid. Komentar atau saran yang diberikan validator terhadap LKS yang dikembangkan yaitu soal pada nomor 2 terlalu banyak (seharusnya 1 poin saja). Hasil skor rata-rata lembar validasi angket respon siswa yang diisi oleh validator ahli dan validator praktisi adalah 3,38 dengan kriteria valid. Tidak ada komentar atau saran yang diberikan validator terhadap LKS yang dikembangkan. Hasil skor rata-rata lembar validasi lembar observasi aktivitas guru yang diisi oleh validator ahli dan validator praktisi adalah 3,5 dengan kriteria valid. Tidak ada komentar atau saran yang diberikan validator terhadap LKS yang dikembangkan. Hasil skor rata-rata lembar validasi lembar observasi aktivitas siswa yang diisi oleh validator ahli dan validator praktisi adalah 3,5 dengan kriteria valid. Tidak ada komentar atau saran yang diberikan validator terhadap LKS yang dikembangkan.

Data hasil uji kepraktisan LKS diketahui berdasarkan angket respon siswa, lembar observasi aktivitas guru dan lembar observasi aktivitas siswa. Hasil skor rata-rata angket respon siswa yang telah diisi oleh 21 siswa adalah 3,5 dengan kriteria praktis. Hasil skor ratarata lembar observasi aktivitas guru yang diisi oleh dua observer untuk 2 kali pertemuan adalah 3,8 dengan kriteria praktis. Hasil skor rata-rata lembar observasi aktivitas siswa yang diisi oleh dua observer untuk 2 kali pertemuan adalah 3,66 dengan kriteria praktis.

Data hasil uji keefektifan LKS diketahui berdasarkan hasil tes formatif siswa setelah menyelesaikan 6 soal tes formatif. Hasil tes formatif menunjukkan bahwa 90\% siswa dinyatakan tuntas, oleh karena itu dapat dikatakan bahwa LKS yang dikembangkan berperan efektif dalam pembelajaran.

\subsection{Pembahasan}

Penelitian ini mengembangkan Lembar Kegiatan Siswa (LKS) berbasis discovery learning pada materi bentuk aljabar untuk siswa kelas VII SMP Miftahul Huda Kabupaten Blitar. LKS yang dikembangkan memenuhi kriteria kualitas produk merujuk pada Nieveen (dalam Hobri, 2010) yaitu valid, praktis, dan efektif. LKS yang dikembangkan telah diuji kevalidan, kepraktisan, dan keefektifannya. Kriteria valid diperoleh berdasarkan hasil validasi oleh validator ahli serta validator praktisi, kriteria praktis diperoleh dari hasil angket respon siswa, lembar observasi aktivitas guru dan siswa, sedangkan kriteria efektif didapat dari hasil tes formatif siswa. 
Hasil validasi terhadap LKS, RPP, tes formatif, angket respon siswa, lembar observasi aktivitas guru dan siswa oleh validator ahli dan validator praktisi menunjukkan skor ratarata seluruh aspek $\left(V_{a}\right)$ yang diperoleh berada pada rentang $3 \leq V_{a} \leq 4$. Dengan demikian berdasarkan kriteria penilaian kevalidan produk maka dapat dikatakan bahwa LKS, RPP, tes formatif, angket respon siswa, lembar observasi aktivitas guru dan siswa yang dikembangkan dinyatakan valid dan dapat diujicobakan dalam pembelajaran di kelas.

Selanjutnya LKS, RPP, tes formatif, angket respon siswa, lembar observasi aktivitas guru dan siswa yang telah divalidasi diterapkan pada uji coba lapangan yaitu siswa kelas VII SMP Miftahul Huda Kabupaten Blitar sebanyak 21 siswa. Uji coba dilakukan untuk menilai kepraktisan dan keefektifan LKS yang dikembangkan. Uji coba lapangan dilaksanakan pada tanggal 29 dan 30 November 2018.

Menurut Nieveen (dalam Hobri, 2010) suatu produk pembelajaran dikatakan praktis jika produk tersebut mudah dan dapat dimanfaatkan oleh guru dan siswa dalam pembelajaran. Berkaitan dengan produk yang dikembangkan, dalam hal ini LKS yang dikembangkan telah memenuhi kriteria praktis. Hal ini dapat dilihat dari terlaksananya seluruh komponen LKS oleh guru dan juga materi serta tahapan dalam LKS mudah diikuti oleh siswa sehingga LKS mampu memfasilitasi guru dan siswa dalam pembelajaran di kelas.

Tingkat kepraktisan LKS diperoleh dari skor hasil observasi aktivitas guru dan siswa dalam menggunakan LKS pada dua kali pertemuan dengan skor rata-rata $P_{r}=3,66$. Skor tersebut berada di rentang $3 \leq P_{r}<4$, sehingga berdasarkan kriteria yang telah ditetapkan maka LKS dinyatakan praktis. Selain itu, kepraktisan LKS juga dapat dilihat dari angket respon siswa yang memperoleh skor rata-rata $P_{r}=3,5$. Skor ini juga berada pada rentang $3 \leq P_{r}<4$, sehingga berdasarkan kriteria yang telah ditetapkan maka LKS dinyatakan praktis.

Selain valid dan praktis, LKS yang dikembangkan juga memenuhi kriteria efektif. Menurut Nieveen (dalam Hobri, 2010) indikator keefektifan suatu produk pembelajaran dapat dilihat dari hasil belajar. LKS dikatakan efektif apabila minimal 80\% siswa memenuhi ketuntasan tes formatif (Hobri, 2010). Berdasarkan hasil tes formatif dari 20 siswa diketahui bahwa persentase siswa yang tuntas pada tes formatif adalah $90 \%$, maka dapat dikatakan bahwa LKS yang dikembangkan berperan efektif dalam pembelajaran.

\section{Simpulan}

\subsection{Kesimpulan}

Berdasarkan uji kevalidan yang telah dilakukan, hasil validasi LKS memperoleh skor 3,43 dengan kriteria valid. Setelah dinyatakan valid, produk diuji cobakan dan dinyatakan praktis. Produk dinyatakan praktis berdasarkan lembar angket respon siswa, lembar observasi aktivitas guru dan lembar observasi aktivitas siswa. Hasil angket respon siswa memperoleh skor 3,5, hasil lembar observasi aktivitas guru untuk 2 kali pertemuan memperoleh skor 3,8, dan hasil lembar observasi aktivitas siswa untuk 2 kali pertemuan memperoleh skor 3,66. LKS yang dikembangkan juga memenuhi kriteria efektif, dilihat dari 90\% siswa telah tuntas pada tes formatif. Jadi, produk yang dikembangkan layak untuk dijadikan alternatif bahan ajar materi bentuk aljabar bagi kelas VII SMP. 


\subsection{Saran}

Saran untuk pengembangan dan pemanfaatan LKS lebih lanjut, yaitu LKS yang dikembangkan disarankan untuk dapat membiasakan siswa mencermati informasi yang disediakan dan membuat pertanyaan mengenai informasi tersebut, LKS yang dikembangkan disarankan untuk dapat mendorong siswa merumuskan jawaban sementara berdasarkan pertanyaan yang telah mereka buat, LKS yang dikembangkan disarankan untuk dapat melatih siswa mencari, mengumpulkan, dan mengolah informasi sebanyak-banyaknya mengenai materi yang sedang dipelajari, LKS yang dikembangkan disarankan untuk dapat menuntun siswa dalam menyimpulkan materi yang dipelajari, LKS yang dikembangkan disarankan untuk dapat mencantumkan masalah kontekstual yang mengarah ke konsep yang dipelajari, serta LKS yang dikembangkan disarankan untuk dapat menambah latihan soal yang bervariasi agar siswa dapat berlatih menerapkan konsep yang dipelajari.

\section{Daftar Rujukan}

Hobri, H. (2010). Metodologi penelitian pengembangan (aplikasi pada penelitian pendidikan matematika). Jember: Pena Salsabila.

Muhardi. (2018). Model pembelajaran discovery learning. Jurnal Ilmiah Ilmu-ilmu Keislaman, 6(11), 133148.

Mendikbud, R. I. (2016). Permendikbud No. 024 Tahun 2016 tentang kompetensi inti (KI) dan kompetensi dasar (KD) pada jenjang pendidikan dasar dan pendidikan menengah.

Trianto. (2010). Mendesain model pembelajaran inovatif-progresif. Jakarta: Kencana Prenada Media Grup.

Zahid, M. Z., \& Sujadi, I. (2017). Pembentukan Konsep Faktorisasi Aljabar Siswa Berkemampuan Tinggi. Kreano, Jurnal Matematika Kreatif-Inovatif, 8(1), 94-100. 